\title{
Document Status
}

National Cancer Institute

\section{Source}

National Cancer Institute. Document Status. NCI Thesaurus. Code C70865.

A condition of a document indicating its relative position or state of affairs in relation to other documents and/or activities, especially in regard to document processing. 